\title{
Biotransformation of flaxseed meal by effective microorganisms and possibility of application in aquaculture
}

\author{
Irina A. Sazonova ${ }^{1, *}$, Tatyana S. Osina ${ }^{1}$, Petr V. Smutnev ${ }^{1}$, Elena $G$. Zhnichkova $^{1}$, and \\ Sergey $V$. Shpul ${ }^{1}$ \\ ${ }^{1}$ Saratov State Agrarian University named after N.I. Vavilova, Department of Microbiology, \\ Biotechnology and Chemistry, 410012 Saratov, Russia
}

\begin{abstract}
This article describes studies on the impact of effective microorganisms of the "Baikal EM-1" probiotic on the biotransformation of flaxseed meal, its organoleptic and chemical parameters, and changes in amino acid and fatty acid compositions. It has been established that after fermentation in flaxseed meal, the amount of fiber decreases, it saturates with protein, and the amount of essential and non-essential amino acids increases. We made an analysis of the feed value of biotransformed meal depending on the probiotic concentration for the purpose of further use in the feeding of carps - the most effective probiotic concentration for biotransformation was selected. The effect of replacing part of the feed with biotransformed flaxseed meal on the change in liveweight and biochemical parameters of fish blood was studied. Positive dynamics of fishes' liveweight was noted. The inexpediency of feeding unfermented meal to carps is proved.
\end{abstract}

\section{Introduction}

Human activity and development of agricultural sector activities leads to the formation of a large amount of waste of various origin, which have a negative impact on the environment.

Currently, many studies of scientists are devoted to the study of waste management using biotechnological methods. It is possible to obtain effective fertilizers by fermentation as a result of biotransformation processes $[1,2,3,4]$. It has been proven that biological products containing various associations of microorganisms affect the fermentation rate [5].

It should be noted that using biotechnological processes makes it possible not only to reduce human impact on the environment, but also to obtain useful substances of various purposes [6,7]. Currently, probiotic microorganisms are widely used for the disposal of agricultural waste. They include enzyme systems that persistently work with waste components. Many studies confirm that fact $[8,9]$. The so-called effective microorganisms have now gained great popularity [10]. Several probiotics are known: "Baikal-EM1", "Urga", "Bokashi", "EM-5", "Tamir", "EM-kurunga" and others. Of particular interest are the studies

\footnotetext{
*Corresponding author: sazonova-sgau@mail.ru
} 
that evaluate the positive role of effective microorganisms in the utilization of agricultural waste and various wastewaters $[11,12,13]$.

Since 1998, EM products of domestic production have been used in Russia, which are created from microorganisms of the Baikal ecosystem. They consist of five families: photosynthetic bacteria; lactic acid bacteria; yeast; actinomycetes; fermenting fungi and fungi such as Aspergillus and Penicillium.

Along with the foregoing, the introduction of industrial waste, fermented with the help of microorganisms, into the diet of farm animals and fish is a very urgent task. To date, the great importance of waste processing of grain, alcohol and beer in the feeding of farm animals and poultry is acknowledged. One of the directions is use of oilseed residues, namely oil meal, as highly nutritious feed additives. Such meals contain a sufficient amount of complete protein, fat, biologically active substances and minerals $[14,15]$. The resulting meal with high humidity quickly molds, rancidifies and forms oxidation products. This complicates its longterm storage. There are several studies about crushing the meal before further use [16,17]. Researchers have now substantiated the permissible standards for using different types of oil meals in feeding technology, depending on the type and age of the animal [18].

Since the oilseed residues includes hardly decomposable deposits of fiber and other polysaccharides, alternative methods of their transformation are being studied [19].

The objective of this research was to study the properties of flaxseed meal after biotransformation using a consortium of microorganisms, and its further use in fish feeding. It is assumed that effective microorganisms will hydrolyze fiber during the meal fermentation, preserving the level of protein and amino acids.

\section{Materials and methods}

The flaxseed meal that was used in the experiments, was the vegetable oil residue, which was obtained by non-waste cold pressing technology. The organoleptic and physicochemical properties were initially determined by conventional methods. The amino acid composition of the meal was determined on the analyzer by capillary electrophoresis. The fatty acid composition of the meal was examined by gas chromatography.

In order to carry out the fermentation experiment, the cake was divided into 3 sets: the $1^{\text {st }}$ one is the experimental set (probiotic treatment at a 1:10 dilution), the $2^{\text {nd }}$ set is the other experimental set (probiotic treatment at a 1:100 dilution), the $3^{\text {rd }}$ set is the control set (without probiotic treatment). The "Baikal EM-1" solution was made at the rate of $10 \%$ by weight of the tested meal. Fermentation was carried out at a temperature of $25{ }^{\circ} \mathrm{C}$ under anaerobic conditions. The chemical composition of the meal was examined on the $15^{\text {th }}$ and $30^{\text {th }}$ day of the experiment.

An integral part of the studies was the determination of the liveweight of carp and the biochemical parameters of fish blood serum. An experiment on the feeding of fish was carried out on the basis of the Industrial Fish Farming Centre of the Saratov State Agrarian University. 3 groups of carps were formed: the $1^{\text {st }}$ control group (feeding was carried out with the «Furgeon Grover" feed), the $2^{\text {nd }}$ experimental group ( $20 \%$ of unfermented flaxseed meal was added to the feed), the $3^{\text {rd }}$ experimental group ( $20 \%$ of biotransformed meal was added to the feed).

\section{Results and discussion}

It is well known that flaxseeds incorporate a large number of biologically active substances. They include proteins, containing all the essential amino acids and polyunsaturated fatty 
acids with a predominance of the most valuable $\omega-3$ fatty acids [20]. Such a composition testifies to the value of seed processing products, namely the meal.

As a result of initial studies on chemical composition of fresh oil meal, it was found that flaxseed meal with a moisture content of $5.67 \pm 0.16 \%$ contained $34.56 \pm 0.16 \%$ of "crude" protein, $16 \pm 0.04 \%$ of fat, $8.85 \pm 0.13 \%$ of fiber, $6.15 \pm 0.08 \%$ of minerals and $28.77 \pm 0.15 \%$ of nitrogen-free extractive substances.

When studying the amino acid composition of the protein (Table 1), which is part of flaxseed meal, it was found that the lowest content among the essential amino acids was of methionine (except tryptophan). A large amount of leucine was also present. In general, the meal contained the entire spectrum of essential and nonessential amino acids that characterize the usefulness of the protein, amounting to 10.4 and $24.75 \mathrm{~g}$ per $100 \mathrm{~g}$ of protein, respectively. The acknowledgements should be typed in 9-point Times, without title.

Table 1. Amino acid and fatty acid composition of flaxseed meal.

\begin{tabular}{|c|c|c|c|}
\hline Amino acids & $\begin{array}{c}\text { Protein in } \\
\mathrm{g} \text { per } 100 \\
\mathrm{~g}\end{array}$ & Fatty acids & $\begin{array}{c}\text { Content in } \\
\%\end{array}$ \\
\hline Essential amino acids, & $172+01$ & \multirow{8}{*}{$\begin{array}{l}\text { Saturated fatty acids, } \\
\text { including: } \\
\text { Palmitic acid } \\
\text { Stearic acid } \\
\text { Arachidic acid } \\
\text { Behenic acid }\end{array}$} & \multirow{8}{*}{$\begin{array}{c}6.51 \pm 0.3 \\
2.93 \pm 0.2 \\
0.52 \pm 0.03 \\
0.06 \pm 0.01\end{array}$} \\
\hline Valine & $1.39 \pm 0.1$ & & \\
\hline Lysin & $1.65 \pm 0.1$ & & \\
\hline Phenylalanine & $2.19 \pm 0.1$ & & \\
\hline Leucine & $1.55 \pm 0.1$ & & \\
\hline Isoleucine & $0.57 \pm 0.01$ & & \\
\hline Methionine & $1.32 \pm 0.1$ & & \\
\hline Threonine & & & \\
\hline Nonessential amino acids, & & Monounsaturated fatty & \\
\hline including: & $3.29 \pm 0.1$ & acids, including: & $0.07 \pm 0.01$ \\
\hline Arginine & $1.02 \pm 0.1$ & Palmitoleic acid & $19.85 \pm 0.3$ \\
\hline Tyrosine & $0.79 \pm 0.01$ & Oleic acid & $0.01 \pm 0.004$ \\
\hline Histidine & $1.56 \pm 0.1$ & Erucic acid & \\
\hline Proline & $1.47 \pm 0.1$ & & \\
\hline Serine & $2.14 \pm 0.11$ & Polyunsaturated fatty & \\
\hline Alanine & $1.93 \pm 0.1$ & acids, including: & $16.87 \pm 0.3$ \\
\hline Glycine & $4.35 \pm 0.12$ & Linoleic acid & $53.82 \pm 0.5$ \\
\hline Aspatic acid & $7.56 \pm 0.15$ & Linolenic acid & \\
\hline Glutamic acid & $0.64 \pm 0.01$ & & \\
\hline Cysteine & & & \\
\hline
\end{tabular}

When studying the meal's fatty acid composition, the affiliation of fatty acids to various groups having their own properties was taken into account. Particularly valuable from a biological point of view are the unsaturated fatty acids. It was found that oleic acid is the most important among the monounsaturated fatty acids, and linolenic acid was the highest among the polyunsaturated fatty acids.

The next research step was the fermentation of flaxseed meal, so a scheme was drawn up and optimal conditions for the experiment were selected.

Flaxseed meal under the influence of effective microorganisms had no detected significant shifts in the amount of hygroscopic moisture (Table 2) after biotransformation on the $15^{\text {th }}$ and $30^{\text {th }}$ day of the experiment. At the same time, it was found that the protein content was reduced by $4 \%$ in the control set after 15 days compared with the freshly obtained meal. By the $30^{\text {th }}$ day of the experiment, this decrease continued by $6 \%$. We did not observe this in the experimental sets. 
Table 2. Chemical indicators of flaxseed meal after fermentation.

\begin{tabular}{|c|c|c|c|c|}
\hline \multirow{2}{*}{$\begin{array}{c}\text { Day of } \\
\text { experiment }\end{array}$} & \multirow{2}{*}{ Indicators, \% } & \multirow{2}{*}{ Control set } & \multicolumn{2}{|c|}{ Experimental sets } \\
\hline & & & $1: 10$ & $1: 100$ \\
\hline \multirow{6}{*}{ 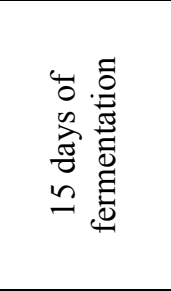 } & $\begin{array}{l}\text { Hygroscopic } \\
\text { moisture }\end{array}$ & $4.46 \pm 0.01$ & $4.03 \pm 0.01 *$ & $4.03 \pm 0.01 *$ \\
\hline & Crude ash & $9.67 \pm 0.01$ & $11.63 \pm 0.01 *$ & $11.63 \pm 0.01 *$ \\
\hline & Crude fiber & $8.32 \pm 0.01$ & $7.59 \pm 0.003^{*}$ & $7.58 \pm 0.003 *$ \\
\hline & Crude protein & $33.35 \pm 0.01$ & $34.18 \pm 0.01 *$ & $34.18 \pm 0.01 *$ \\
\hline & Crude fat & $15.91 \pm 0.004$ & $16.54 \pm 0.004 *$ & $16.54 \pm 0.004^{*}$ \\
\hline & NFE fractions & $28.29 \pm 0.01$ & $26.03 \pm 0.01^{*}$ & $26.03 \pm 0.01^{*}$ \\
\hline \multirow{6}{*}{ 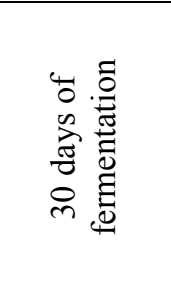 } & $\begin{array}{l}\text { Hygroscopic } \\
\text { moisture }\end{array}$ & $4.84 \pm 0.01$ & $4.85 \pm 0.01 *$ & $4.71 \pm 0.001 *$ \\
\hline & Crude ash & $9.61 \pm 0.01$ & $9.67 \pm 0.03 *$ & $8.67 \pm 0.01 *$ \\
\hline & Crude fiber & $7.85 \pm 0.01$ & $7.41 \pm 0.01 *$ & $7.66 \pm 0.01 *$ \\
\hline & Crude protein & $32.57 \pm 0.003$ & $34.28 \pm 0.01 *$ & $34.32 \pm 0.01 *$ \\
\hline & Crude fat & $15.48 \pm 0.002$ & $16.88 \pm 0.01 *$ & $16.68 \pm 0.01$ \\
\hline & NFE fractions & $29.66 \pm 0.01$ & $26.92 \pm 0.01 *$ & $27.97 \pm 0.05^{*}$ \\
\hline
\end{tabular}

Note: $\mathrm{P}$ in relation to the control set: * $-<0.001$

When treating meal with 1:10 microorganisms, the amount of protein was $3 \%$ higher than in the control set, and $4 \%$ higher when diluted at 1:100. Therefore, the initial level of protein is almost preserved in the flaxseed meal due to the microorganism treatment. Changes in the content of crude fat are also presented in Table 2. Fat content of the experimental sets exceeded the control set value by $4 \%$ in the $1^{\text {st }}$ set, by $2 \%$ in the $2^{\text {nd }}$ set, respectively. Amount of fat in the experimental meal sets remained at the initial level by the $30^{\text {th }}$ day of fermentation. Consequently, probiotics also contributed to the meal's lipidization. We also found that the amount of fiber in the control set practically did not change. The situation for the experimental sets was the opposite. On the $15^{\text {th }}$ day of the experiment, the fiber level was lower by $9 \%$ in the $1^{\text {st }}$ experimental set, and by $7 \%$ in the $2^{\text {nd }}$ experimental set, in comparison with the control set. More significant changes occurred by the $30^{\text {th }}$ day of fermentation: in comparison with the control set, the amount of fiber decreased by $6 \%$ in the $1^{\text {st }}$ experimental set and by $3 \%$ in the $2^{\text {nd }}$ set.

As for the amino acid composition of meal protein after 15 days of fermentation, it should be noted that the total number of amino acids increased slightly in the experimental sets: the sum of the essential amino acids increased by $46 \%$ when diluting the probiotic at $1: 10$; and by $74 \%$ when diluting at $1: 100$. The sum of the nonessential amino acids increased by $50 \%$ when diluting the probiotic at 1:10; and by $55 \%$ when diluting at $1: 100(\mathrm{P}<0.001)$ (Table 3$)$. By the $30^{\text {th }}$ day of fermentation, the number of amino acids continued to increase. The increase in amino acids, apparently, is associated with the synthesis of their microorganisms, which are part of the probiotic during fermentation. This explains the decrease in amino acid levels in the control group, where no effective microorganisms were present. In addition, amino acids could be formed from liquid acids, which are formed during anaerobic fermentation. In the control meal set, a decrease in amino acids was observed during the entire experiment: by $11 \%$ of essential and by $12 \%$ of nonessential amino acids after 15 days of the experiment and by $28 \%$ and $23.5 \%$ after 30 days of the experiment, respectively $(\mathrm{P}<0.001)$.

When studying the changes in the fatty acid composition of flaxseed meal during biotransformation, we noted a significant decrease in the number of all groups of higher fatty acids during the experiment in all sets (Table 3). It is scientifically proven that higher fatty acids undergo attenuation during anaerobic fermentation, which provokes the breaking of the carbon chain and the formation of liquid acids, glycerol and other intermediate metabolites. A more intense decrease in the amount of fatty acids was observed in experimental meal sets with the probiotic addition, which indicates the effort of effective microorganisms during the experiment. Moreover, the decomposition of fatty acids was observed most intensively in the experimental set with a probiotic at a dilution of $1: 100$, which indicates the most favorable environment for microorganisms. Almost all types of fatty acids, which were determined within the analyzer, decreased in quantitative terms by almost 2 times during fermentation $(\mathrm{P}<0.001)$. Saturated and monounsaturated fatty acids underwent the most severe breakdown. 
Table 3. Amino acid and fatty acid composition of flaxseed meal after fermentation.

\begin{tabular}{|c|l|c|c|c|}
\hline $\begin{array}{c}\text { Day of } \\
\text { experiment }\end{array}$ & \multicolumn{1}{|c|}{ Indicators, \% } & Control & \multicolumn{2}{|c|}{ Experimental sets } \\
\cline { 4 - 5 } & & set & $1: 10$ & $1: 100$ \\
\hline \multirow{3}{*}{$\begin{array}{c}15 \text { days of } \\
\text { fermentation }\end{array}$} & Sum of essential amino acids & $9.29 \pm 0.2$ & $16.91 \pm 0.1$ & $18.11 \pm 0.1$ \\
& Sum of nonessential amino acids & $21.8 \pm 0.1$ & $34.3 \pm 0.2$ & $38.29 \pm 0.1$ \\
& Saturated fatty acids & $10.83 \pm 0.1$ & $4.95 \pm 0.1$ & $4.35 \pm 0.1$ \\
& Monounsaturated fatty acids & $18.63 \pm 0.2$ & $13.44 \pm 0.1$ & $12.79 \pm 0.1$ \\
& Polyunsaturated fatty acids & $67.83 \pm 0.3$ & $57.16 \pm 0.2$ & $53.87 \pm 0.1$ \\
\hline \multirow{3}{*}{30 days of } & Sum of essential amino acids & $7.53 \pm 0.1$ & $24.66 \pm 0.1$ & $27.27 \pm 0.1$ \\
fermentation & Sum of nonessential amino acids & $18.93 \pm 0.1$ & $56.98 \pm 0.3$ & $62.12 \pm 0.2$ \\
& Saturated fatty acids & $7.17 \pm 0.1$ & $4.19 \pm 0.1$ & $3.91 \pm 0.01$ \\
& Monounsaturated fatty acids & $16.58 \pm 0.1$ & $14.59 \pm 0.1$ & $14.03 \pm 0.1$ \\
& Polyunsaturated fatty acids & $66.75 \pm 0.2$ & $53.18 \pm 0.2$ & $51.94 \pm 0.1$ \\
\hline
\end{tabular}

As a result of the experiment, it was concluded that flaxseed meal, due to its characteristics and biological value, can be used as a highly effective feed additive in the diets of farm animals and fish. Considering the obtained data, we selected flaxseed meal after biotransformation with the "Baikal EM1 " probiotic at a dilution of 1:100 for 30 days, to further study its effect on the growth and development of carps.

The liveweight of carps was measured in dynamics (Fig. 1). As a result, it was noted that during growth, fish that were fed with the addition of untreated meal had lesser weight than in the control group: after 1 month - the weight decreased by $9 \%$, after 2 months - by $18 \%, 3$ months - by $22 \%, 4$ months $-22 \%(\mathrm{P}<0.001)$. The liveweight of the $3^{\text {rd }}$ experimental group throughout the experiment was almost at the same level as the control group $(\mathrm{P}>0.05)$.

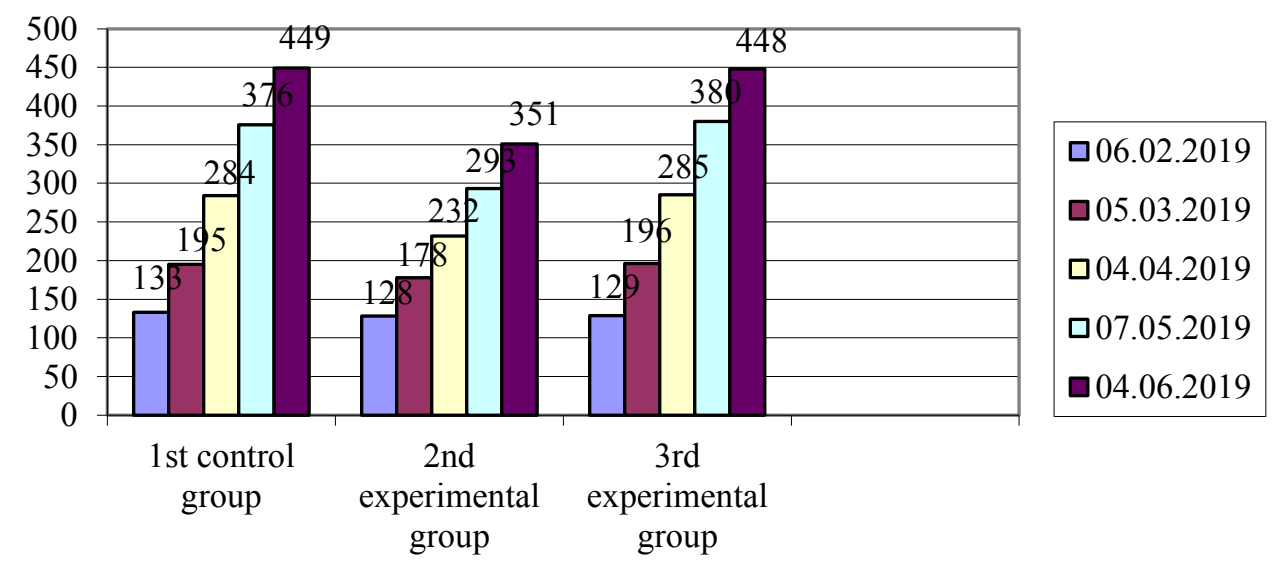

Fig. 1. Carps' liveweight dynamics.

The biochemical parameters characterizing the level of metabolism in the fish organisms were examined after 4 months of feeding. All indicators were within the physiological standards (Table 4). At the same time, the level of total protein in blood serum of the $2^{\text {nd }}$ fish group was lower than in the other groups: by $34 \%$ in comparison with the control group and by $36 \%$ in comparison with the $2^{\text {nd }}$ experimental group. This may indicate a lower intensity of protein metabolism and is confirmed by a decrease in the total fish's weight. Therefore, it is more advisable to use flaxseed meal, which was fermented with a consortium of microorganisms, in the feeding of fish. 
Table 4. Biochemical indicators of carps.

\begin{tabular}{|c|c|c|c|c|}
\hline Indicators & $\begin{array}{c}\text { Regular } \\
\text { feed }\end{array}$ & $\begin{array}{c}\text { Feed with fresh } \\
\text { meal }\end{array}$ & $\begin{array}{c}\text { Feed with fermented } \\
\text { meal }\end{array}$ & Standards \\
\hline $\begin{array}{c}\text { Total protein, } \\
\mathrm{g} / \mathrm{l}\end{array}$ & $5.2 \pm 0.1$ & $35.1 \pm 0.1^{*}$ & $5.5 \pm 0.1$ & $25-70$ \\
\hline $\begin{array}{c}\text { Cholesterol, } \\
\mathrm{mol} / \mathrm{l}\end{array}$ & $8.2 \pm 0.01$ & $8.1 \pm 0.01$ & $8.3 \pm 0.01$ & $7.5-10.5$ \\
\hline Glucose, $\mathrm{mol} / 1$ & $5.1 \pm 0.02$ & $4.2 \pm 0.01$ & $4.9 \pm 0.01$ & $2.0-11.0$ \\
\hline Urea, $\mathrm{mol} / 1$ & $4.2 \pm 0.01$ & $3.6 \pm 0.02$ & $4.2 \pm 0.01$ & $2.5-6.3$ \\
\hline ASAT, units/1 & $75.6 \pm 0.2$ & $72.2 \pm 0.5$ & $70.4 \pm 0.1$ & $13-176$ \\
\hline ALAT, units/l & $53.7 \pm 0.1$ & $50.8 \pm 0.3$ & $52.2 \pm 0.5$ & $23-99$ \\
\hline
\end{tabular}

Note: $* \mathrm{P}<0.001$

\section{Conclusion}

Flaxseed meal processing products got acknowledge not only in the feed production, but also in the food industry [20,21]. Analysis of the chemical composition of flaxseed meal suggests that it can be attributed to a valuable nutritious feed component that can make up for many substances that are essential for a living organism.

We used the fermentation process in order to increase the biological value of flaxseed meal under the action of the "Baikal EM-1" probiotic. As a result of the studies, it was proved that microorganisms are able to break down a significant amount of fiber in flaxseed meal - from $1 \%$ to $11 \%$ within the 30 days of meal biotransformation. During the fermentation of flaxseed meal with the "Baikal EM-1" product, the amount of amino acids significantly increases due to the microbial mass and the breakdown products of higher fatty acids. It was found that the dynamics of fish's liveweight was positive as a cause of feeding the carps with flaxseed meal, fermented with a probiotic for 30 days, and their metabolic state was normal, as evidenced by biochemical parameters.

\section{References}

1. O. I. Gavrilova, V. M. Prokopyuk, International journal of applied and fundamental researches 12, 277 (2018)

2. V. V. Kireeva, T. G. Rasskazova, A. N. Mikhailova, R. I. Larsky, Proceedings of 11th international scientific and practical conference in the framework of the $21^{\text {st }}$ international agricultural exhibition "Interagromash-2018”, 493 (DGTU-PRINT, Rostov-on-Don, 2018)

3. E. I. Magradze, Othody, prichiny ih obrazovaniya i perspektivy ispol'zovaniya [Ecology Conference Proceedings. Waste, its causes and application prospects] (Kuban State Agrarian University, Krasnodar, 2019)

4. A. Yu. Maximov, Yu. G. Maksimova, A. V. Shilova, Mikrobnye biotekhnologii: fundamental'nye $i$ prikladnye aspekty [Research paper collection Microbial Biotechnology: Fundamental and Applied Aspects] (Belorusskaya nauka, Minsk, 2019)

5. K. V. Evdokimova, Aktual'naya biotekhnologiya 3, 559 (2018)

6. J. Kour, D. C. Saxena, Austin Journal of Nutrition and Food Sciences 2, 1 (2014)

7. S. H. Park, S. N. Ryu, Y. Bu, H. Kim, J. E. Simon, K. S. Kim, Food Reviews International 26, 103 (2010). DOI: 10.1080/87559120903564464

8. A. Ya. Yakhin, Meat industry 1, 35 (2003)

9. K. K. Bolsen, R. Smith, H. Ilg Fung, Y. C. Daniel, Kansas Agricultural Experiment Station Research Reports 0, 109 (1986). DOI: 10.4148/2378-5977.2431 
10. D. A. Bochkov, Prioritetnye napravleniya issledovanij $v$ ramkah estestvennyh $i$ tekhnicheskih nauk v XXI veke [International Conference Proceedings Priority areas of research in the framework of natural and technical sciences in the XXI century], 62 (Agentstvo perspektivnyh nauchnyh issledovanij, Belgorod, 2018)

11. A. Zh. Ayupova, E. Zh. Khasenova, D. Zh. Sembaeva, Vestnik Nauki i Obrazovaniya 13-1, 58 (2019)

12. A. A. Rozovik, R. A. Nebuchin, Ekologiya goroda [Proceedings of $2^{\text {nd }}$ regional scientific-practical conference for urban institutions and enterprises of Amur Region Urban Ecology], 55 (Far Eastern State Agrarian University, Blagoveshchensk, 2018)

13. I. A. Sazonova, A. B. Ivanov, V. A. Pancakes, Bulletin of Saratov State Agrarian University named after N.I. Vavilov 6, 34 (2008)

14. Z. V. Vasilenko, T. N. Bolashenko, E. N. Kucherova, Aktual'nye problemy razvitiya obshchestvennogo pitaniya i pishchevoj promyshlennosti [Proceedings of international scientific-practical and methodological conference Actual problems of the development of public catering and the food industry], 57 (Belgorod University of Cooperation, Economics and Law, Belgorod, 2018)

15. N. S. Voronova, L. S. Middle, Sovremennye tendencii tekhnicheskih nauk [Proceedings of IV international scientific conference Current Trends in Technical Sciences], 93 (Buk, Kazan, 2015)

16. A. N. Kubasova, V. I. Manzhesov, O. Yu. Gubanova, Mezhdunarodnyj studencheskij nauchnyj vestnik 3-3, 353 (2015)

17. L. N. Lishayova, T. N. Turchina, O. V. Kirillova, N. I. Nazarova, Maslozhirovaya promyshlennost' 4, 12 (2010)

18. V. A. Zubtsov, D. P. Efremov, E. V. Zubtsova, Prioritety i perspektivy ekologoekonomicheskogo razvitiya: regional'nyj $i$ municipal'nyj aspekty [Proceedings of international scientific-practical conference Priorities and prospects of environmental and economic development: regional and municipal aspects], 400 (Rosinformagrotech, Moscow, 2018)

19. I. E. Minevich, L. L. Osipova, I. V. Ushapovsky, Khleboprodukty 8, 34 (2019). DOI: 10.32462/0235-2508-2019-30-8-34-37

20. L. I. Podobed, Effektivnoe zhivotnovodstvo 5, 46 (2019)

21. L. E. Enzifst, M. E. Bveo, Food New Zealand 1, 26 (2014) 